\title{
Response paper: Morphometric article by Mejía et al. 2015 alluding genera Herichthys and Nosferatu displays serious inconsistencies
}

\author{
Mauricio de la Maza-Benignos ${ }^{1}$, Ma. de Lourdes Lozano-Vilano ${ }^{2}$ and María Elena \\ García-Ramírez ${ }^{2}$
}

In the present response paper, the article entitled "Morphometric variation of the Herichthys bartoni (Bean, 1892) species group (Teleostei: Cichlidae): How many species comprise H. labridens (Pellegrin, 1903)?” by Mejía et al. 2015 is critically reviewed. The current review pinpoints some of the more conspicuous conceptual inconsistencies and fundamental errors found in the study by Mejía et al. (2015), It is contended that the authors fail to provide any new insights into the complex biogeography and evolutionary history of the Nosferatu and Herichthys genus groups, and that while results of their Cox1 molecular analysis are comparable to those by De la Maza-Benignos et al. (2015), the conclusions of the two studies are not comparable. In addition, it is contested that, whereas the designation of genus Nosferatu by De la MazaBenignos et al. (2015) was found on the principles of the biological and phylogenetic species concepts, the rejection of the genus by Mejía et al. (2015) is solely based "on the presence of (overlapping) morphometric characters" between genera. The assumption by Mejía et al. (2015), that because their geometric morphometrics analysis failed to provide separation of species, then Nosferatu genus does not correspond to a valid taxon; and their suggesting geometric morphometrics "as useful tool to discriminate species, because it allows to propose diagnostic characters" were not supported by their results. While Mejía et al. present some interesting thoughts on the systematics of Nosferatu, they unfortunately fail to provide any data that can be objectively assessed as relevant to motivate any changes in the current taxonomy.

El presente documento de respuesta analiza críticamente el artículo titulado "Morphometric variation of the Herichthys bartoni (Bean, 1892) species group (Teleostei: Cichlidae): How many species comprise H. labridens (Pellegrin, 1903)?" por Mejía et al. (2015), así como también evidencia algunas de las contradicciones conceptuales y errores fundamentales encontrados en dicho documento. Se arguye que el artículo no proporciona ningún aspecto nuevo acerca de la compleja biogeografía, ni de la historia evolutiva de los géneros Nosferatu y Herichthys, y que mientras que los resultados del análisis molecular utilizando el gen Cox1 son similares a los de la Maza-Benignos et al. (2015), las conclusiones de ambos estudios no son compatibles. Se contiende además que mientras que la designación del género Nosferatu por De la Maza-Benignos et al. (2015) se fundamentó en principios asociados a los conceptos biológico y filogenético de especie, el rechazo del género por Mejía et al., (2015) únicamente se basa "en la existencia de caracteres morfométricos (superpuestos)" entre géneros. La inferencia por parte de Mejía et al. de que debido a que el análisis de morfometría geométrica no logró separar a las especies, y que por lo tanto el género Nosferatu no corresponde a un taxón válido; así como la observación de que la morfometría geométrica corresponde a "una herramienta útil para diferenciar especies, porque permite proponer caracteres de diagnóstico" no están sustentadas por los resultados de su análisis, y mientras que Mejía et al., presentan algunas ideas interesantes sobre la sistemática de Nosferatu, lamentablemente no proporcionan ningún dato relevante que pueda ser evaluado objetivamente como para motivar cambios en la taxonomía actual.

Keywords: Cox 1, Genera, Geometric morphometrics, Monophyly requirement, Paraphyletic, Species concepts.

\section{Introduction}

In the present paper, we wish to challenge the study entitled "Morphometric variation of the Herichthys bartoni (Bean, 1892) species group (Teleostei: Cichlidae): How many species comprise H. labridens (Pellegrin, 1903)?" by Mejía et al. (2015). We review and comment on some of the more serious shortcomings of the aforementioned study. Also, we pinpoint some of the more noticeable conceptual inconsistencies and errors that characterize their manuscript.

${ }^{1}$ Pronatura Noreste, A.C., Loma Grande 2623, Col. Loma Larga, Monterrey, 64710 N.L, Mexico. mmaza@pronaturane.org (corresponding author)

${ }^{2}$ Laboratorio de Ictiología, Facultad de Ciencias Biológicas, UANL, Ap. Postal 425 San Nicolás de los Garza, 66450 N.L, Mexico. 


\section{Material and Methods}

Research article entitled "Morphometric variation of the Herichthys bartoni (Bean, 1892) species group (Teleostei: Cichlidae): How many species comprise $H$. labridens (Pellegrin, 1903)?" published by Mejía et al. in Neotropical Ichthyology, 13(1): 61-76, 2015 was critically reviewed. We evaluated whether the conclusions drawn from their study using DNA barcoding and geometric morphometrics are consistent with the reported results and comparable to previous molecular studies on the systematics and zoogeography of both clades reported in the scientific literature between 2007 and 2015 .

\section{Results}

After a careful examination of the manuscript by Mejía et al. (2015), we consider that, apart from corroborating a few general aspects of both taxa that have been widely known for some time now and have already been published even in the most popular literature (for example, see Wikipedia under Nosferatu (fish) and Herichthys entries), the article fails to provide new insights into the complex evolutionary history and the biogeography of the Nosferatu and Herichthys genera. For more information on the systematics and zoogeography of both clades see Concheiro-Pérez et al. (2007), De la Maza-Benignos \& Lozano-Vilano (2013), De la Maza-Benignos et al. (2015), Hulsey et al. (2004), López-Fernández et al. (2010), LeónRomero et al. (2012), Magalhaes et al. (2015), McMahan et al. (2015) and Oldfield et al. (2015), to name a few.

We will begin by discussing the appropriateness of the title, "Morphometric variation of the Herichthys bartoni (Bean, 1892) species group (Teleostei: Cichlidae): How many species comprise H. labridens (Pellegrin, 1903)?" The title hints to a systematic revision and an update on the number of species within Nosferatu (De la MazaBenignos et al., 2015). However, within their paper, we were unable to identify a ground-breaking discussion which resolves the fundamental issue suggested. Instead, at best, the authors limited their contribution to a brief and often very confusing restatement of results already presented within previous studies. For example, the article concludes, “....an update of a previously published DNA barcoding study suggests the existence of three genetic clusters that included the six recognized species analyzed in this study, none of them recovered as monophyletic" and "On the other hand, geometric morphometrics arise as a useful tool to discriminate species due that [sic] traditional morphometrics showed a high overlap in the characters analyzed that prevents the proposal of diagnostic characters."

The first concluding statement mentioned above, that none of the species were recoveredas monophyletic, is clearly inaccurate. Based on their second concluding statement, we would have expected that their geometric morphometrics evaluation would have allowed them, at least, to disclose a discrete measure of what had passed undetected by previous authors, which would allow separating recognized nominal species without having to recur to canonical functions. Why is it then that except for Nosferatu steindachneri, which had already been validated as a distinct species by De la Maza-Benignos \& Lozano-Vilano (2013) based on similar arguments, that the authors were incapable in their redescriptions to produce a morphometric founded diagnosis for any of the species reviewed? Instead they based their diagnosis on geographic and chromatic characteristics. In our opinion, their morphometric "findings" are contradictive to their conclusion based on geometric morphometrics.

In addition, the manuscript further acknowledges in the Introduction section that there are six "recognized" nominal species in the "group" (i.e. N. labridens, N. bartoni, $N$. steindachneri, N. pame, $N$. pratinus, and N. pantostictus), although, in the Methods section further down, they say that "we include seven taxa: $H$. bartoni, $H$. labridens, $H$. steindachneri, $H$. pantostictus, $H$. pame, $H$. molango, and $H$. cf. labridens, however, we cannot [sic] include samples from $H$. pratinus." This indicates that they constructed $a$ priori determinations that their Herichthys. cf. labridens is a distinct taxon or they accounted for a species $N$. pratinus, which was excluded in the study.

As mentioned earlier, their paper provides a series of redescriptions for the nominal species $N$. bartoni, $N$. labridens, $N$. steindachneri, N. pame, N. pantostictus, and $N$. molango, and, hence, in our view, tacitly validating them (N. pratinus was not included in the work) and ends asserting that "...traditional morphometrics and meristic counts failed to clearly separate species...;" however, "in conclusion, the results of this study regarding geometric morphometrics allow support for the recent proposal of De la Maza-Benignos \& Lozano-Vilano (2013) that H. labridens s.l. comprises several species..." and proposes that "further studies with other molecular markers are necessary....".

Furthermore, their article contains some misreports. For example, in the work by De la Maza-Benignos \& LozanoVilano (2013) and De la Maza-Benignos et al. (2015), the authors clearly indicate that $N$. molango is restricted to Laguna Azteca and suggest that this species is the only native cichlid found in this place. In addition, De la MazaBenignos et al. (2015) suggest that "the species could correspond to a phenomenon of secondary contact between both genera, as $N$. molango exhibited mitochondrial DNA affinity to Herichthys."

In contrast, the paper by Mejía et al. (2015) amends the distribution range of $N$. molango from the original description and arbitrarily assign the species to "...widely distributed in rivers windward of the Sierra Madre Oriental in the states of Hidalgo and San Luis Potosí," without any explanation. Hence, the interpretation by Mejía et al. (2015) of $N$. molango is fundamentally in disagreement with the nominal species sensu stricto, and their analysis based on a composite of $N$. molango and $N$. pantostictus (see 
Material Examined on page 74 of their paper). Moreover, it can be inferred that $N$. molango was not included in their genetic analysis, "because this species was formalin fixed and preserved." Hence, the redescription and their morphometric and molecular conclusions regarding $N$. molango are specious and misleading.

In the introductory section of the paper, Mejía et al. (2015) indicate that there are " 12 currently recognized species (in Herichthys + Nosferatu)," followed by the idea that "recent phylogenetic studies have confirmed the monophyly of the genus but not of the species included in it...." It can in addition be inferred that the authors believe that there remain taxonomically uncertain populations within the group found in the mainstream of the Pánuco and Tamesí rivers at the sites marked with a $\dagger$ on the map in Figure 1, a very improbable situation in our opinion. Thus, we will contend that it is reasonable to assume that the authors could be dealing with a mislabeling and not a taxonomic problem.

Because Mejía et al. (2015) were unable to identify "unique autapomorphies that allow" to distinguish between $N$. labridens and $N$. pantostictus "from the rest of the species of the group," and because they basically disregarded the work by De la Maza-Benignos \& Lozano-Vilano (2013), they appear to have chosen to treat the $H$. cf. labridens tag as a taxonomic unit. Although, based on the localities provided, and the position of such specimens in the phylogenetic tree, it can be inferred that the species labeled as Herichthys sp. labridens corresponds to mislabeled specimens of $N$. pantostictus sensu De la Maza-Benignos \& Lozano-Vilano (2013). Consequently, the apparent polyphyly discrepancy discussed in Mejía et al. (2015) essentially becomes an easily resolved label/tag problem.

The inefficacy of a particular method or genetic marker to discriminate between species, particularly within Herichthys, for example in $H$. carpintis vs. $H$. tamasopoensis (see De la Maza-Benignos et al., 2015), does not signify that differences do not exist. Hence, unlike higher taxonomic ranks, for which we believe phylogenetic analysis should clearly demonstrate both monophyly and validity as a separate lineage in phylogenetic trees, species and subspecies can appear paraphyletic (Crisp \& Chandler, 1996), for example, $N$. bartoni vs. $N$. labridens, depending on the levels of resolution of the genetic markers used. In fact, species-level paraphyly has been reported to occur in $19 \%$ to $23 \%$ of animal species on the basis of a meta-analysis of published mitochondrial gene trees [see: Funk \& Omland (2003), Hörandl (2006), and Ross (2014)].

In the introduction section of their paper, Mejía et al. (2015) "rejected the recent proposal of De la Maza-Benignos et al. (2015), who suggested that the species included in the $H$. labridens species group must be segregated into a new genus named Nosferatu because the morphological characters that support both genera are also present in species of the other genus." No evidence for the above claim is provided, for nowhere in the manuscript is the separation between Nosferatu and Herichthys even analyzed or discussed. Instead, the authors cite an unpublished paper "in preparation" by Pérez-Miranda. The fact is that both genera can be easily distinguished from each other (see De la MazaBenignos et al., 2015) even by the inexperienced eye. Mejía et al. (2015) are of course entitled to "reject" the existence of a genus; however, in academia the onus probandi should fall upon those who make claims.

The authors further state in the results section that "the phylogenetic analysis of the mitochondrial COI confirms the previously published results using COI and other molecular markers that the genus Herichthys comprises a well-supported monophyletic group $(\mathrm{BPP}=1.0)$, and that this genus includes two well-supported clades: the group of species related to $H$. cyanoguttatus $(\mathrm{BPP}=1.0)(=$ Herichthys) and the group of species related to $H$. bartoni analyzed in the current study $(\mathrm{BPP}=1.0)(=$ Nosferatu $) . "$

Whereas the scope of this note is not to provide a full discussion of the trite species problem, a quick review of the biological and the phylogenetic species concepts is relevant to our point. For a more comprehensive discussion regarding the species problem, see Mayr (1970, 1996), Wiley (1978), Cracraft (1983, 1997), Crisp \& Chandler (1996), Kullander (1999), Mishler \& Theriot (2000), Noor (2002), and Wiens (2004), among others.

\section{Discussion}

The classical biological species concept defines species as groups of interbreeding natural populations that are reproductively isolated from other such groups (Mayr, 1970), whereas the phylogenetic species concept considers a species as the smallest recognizable organismal unit in a phylogenetic genealogy, and because there should be no structural difference between taxa of different categories, we will argue that both concepts also apply to the genus rank. For a more comprehensive discussion on the "monophyly requirement" for species rank see Crisp \& Chandler (1996), and Kullander (1999).

In that order of ideas, genera should be composed of phylogenetic units of the same kind as other genera; and both Nosferatu (BPP $=1.0$ according to Mejía et al., 2015) and Herichthys (BPP $=1.0$ according to Mejía et al., 2015) genus groups sensu De la Maza-Benignos et al. (2015) fully meet the underlying criteria of the two concepts. Furthermore, separate molecular analysis by Concheiro-Pérez et al. (2007), De la Maza-Benignos et al. (2015), Hulsey et al. (2004), López-Fernández et al. (2010), León-Romero et al. (2012), Mejía et al. (2015), Magalhaes et al. (2015), McMahan et al. (2015) and Oldfield et al. (2015) support the monophyly of the Nosferatu + Herichthys clade as well as separation between both genera. Moreover, the separate analysis of the mitochondrial gene Cox1 by León-Romero et al. (2012), De la Maza-Benignos et al. (2015), and Mejía et al. (2015) reveal the existence of three clades in Nosferatu: 1) the bartoni clade (= phylogenetic group I sensu Mejía et al., 2015); 2) the steindachneri clade (= phylogenetic group II sensu Mejía 
et al., 2015); and 3) the pantostictus clade (in the study by León-Romero et al. (2012) and Mejía et al. (2015) some of the lineages of $N$. pantostictus are misidentified as $H$. cf. labridens, and consequently, they reported polyphyly).

In conclusion, while morphometric and molecular analysis results by Mejía et al. (2015) and De la Maza-Benignos et al. (2015) are comparable, the conclusions drawn by the two papers are contradictory. The designation of genus Nosferatu by De la Maza-Benignos et al. (2015) was found on the principles of the biological and phylogenetic species concepts, whereas the rejection of the genus by Mejía et al. (2015) is based solely on the lay understanding of what a species is and the presence of (overlapping) morphological characters in both genera, according to an unpublished paper still in preparation. Because geometric morphometrics analysis failed to provide separation of the species, the conclusion from their study that geometric morphometrics is a useful tool to discriminate species as it allows the proposition of diagnostic characteristics is not consistent with their results. Moreover, both papers agree that further molecular analyses using different markers are required. Mejía et al. (2015) present some interesting thoughts on the systematics of Nosferatu; however, unfortunately, they do not provide any data that can be objectively assessed as relevant for motivating any changes in the current taxonomy.

\section{Acknowledgments}

We would like to thank the referees and editors who have contributed to the quality of the final version of this article through their insightful comments and suggestions.

\section{References}

Concheiro Pérez, G. A., O. Řičan, G. Ortí, E. Bermingham, I. Doadrio \& R. Zardoya. 2007. Phylogeny and biogeography of 91 species of heroine cichlids (Teleostei: Cichlidae) based on sequences of the cytochrome $b$ gene. Molecular Phylogenetics and Evolution, 43: 91-110.

Crisp, M. D. \& G. T. Chandler. 1996. Paraphyletic species. Telopea, 6: 813-844.

De la Maza-Benignos, M. \& M. L. Lozano-Vilano. 2013. Description of three new species of the genus Herichthys (Perciformes: Cichlidae) from eastern Mexico, with redescription of $H$. labridens, H. steindachneri, and H. pantostictus. Zootaxa, 3734: 101-129.

De la Maza-Benignos, M., C. P. Ornelas-García, M. L. Lozano-Vilano, M. E. García Ramírez \& I. Doadrio. 2015. Phylogeographic analysis of genus Herichthys (Perciformes: Cichlidae), with descriptions of Nosferatu new genus and H. tepehua n. sp. Hydrobiologia, 748: 201-231.

Cracraft, J. 1983. Species concepts and speciation analysis. Current Ornithology, 1: 159-187.

Cracraft, J. 1997. Species concepts in systematics and conservation biology - an ornithological viewpoint. Pp. 325-339. In: Claridge, M. F., H. A. Dawah \& M. R. Wilson (Eds.). Species: the units of biodiversity. 1 st ed. London, New York, Chapman \& Hall. (The systematics Association special volume series, 54).
Funk, D. J., \& K. E. Omland. 2003. Species-level paraphyly and polyphyly: frequency, causes, and consequences, with insights from animal mitochondrial DNA. Annual Review of Ecology, Evolution, and Systematics, 34: 397-423.

Hörandl, E. 2006. Paraphyletic versus monophyletic taxaevolutionary versus cladistic classifications. Taxon, 55: 564570.

Hulsey, C. D., F. J. García de León, Y. S. Johnson, D. A. Hendrickson \& T. J. Near. 2004. Temporal diversification of Mesoamerican cichlid fishes across a major biogeographic boundary. Molecular Phylogenetics and Evolution, 31: 754-764.

Kullander, S. O. 1999. Fish species - how and why. Reviews in Fish Biology and Fisheries, 9: 325-352.

León-Romero, Y., O. Mejía \& E. Soto-Galera. 2012. DNA barcoding reveals taxonomic conflicts in the Herichthys bartoni species group (Pisces: Cichlidae). Molecular Ecology Resources, 12: 1021-1026.

López-Fernández, H., K. O. Winemiller \& R. L. Honeycutt. 2010. Multilocus phylogeny and rapid radiations in Neotropical cichlid fishes (Perciformes: Cichlidae: Cichlinae). Molecular Phylogenetics and Evolution, 55: 1070-1086.

Magalhaes, I. S., C. P. Ornelas-Garcı, M. Leal-Cardin, T. Ramírez \& M. Barluenga. 2015. Untangling the evolutionary history of a highly polymorphic species: introgressive hybridization and high genetic structure in the desert cichlid fish Herichtys minckleyi. Molecular Ecology, 24: 4505-4520.

Mayr, E. 1970. Populations, species, and evolution: an abridgment of animal species and evolution. Cambridge, Mass., Harvard University Press. 453p.

Mayr, E. 1996. What is a species, and what is not? Philosophy of Science, 63: 262-277.

McMahan, C. D., W. A. Matamoros, K. R. Piller \& P. Chakrabarty. 2015. Taxonomy and systematics of the herichthyins (Cichlidae: Tribe Heroini), with the description of eight new Middle American Genera. Zootaxa, 3999: 211-234.

Mejía, O., F. Pérez-Miranda, Y. León-Romero, E. Soto-Galera \& E. Luna. 2015. Morphometric variation of the Herichthys bartoni (Bean, 1892) species group (Teleostei: Cichlidae): how many species comprise H. labridens (Pellegrin, 1903)?. Neotropical Ichthyology, 13: 61-76.

Mishler, B. D. \& E. C. Theriot. 2000. The phylogenetic species concept (sensu Mishler and Theriot): monophyly, apomorphy, and phylogenetic species concepts. Pp. 44-54. In: Wheeler, Q. D. \& R. Meier (Eds.). Species concepts and phylogenetic theory: a debate. New York, Columbia University Press.

Noor, M. A. F. 2002. Is the biological species concept showing its age? TRENDS in Ecology \& Evolution, 17:153-154.

Oldfield, R. G., K. Mandrekar, M. X. Nieves, D. A. Hendrickson, P. Chakrabarty, B. O. Swanson \& H. A. Hofmann. 2015. Parental care in the Cuatro Ciénegas cichlid, Herichthys minckleyi (Teleostei: Cichlidae). Hydrobiologia, 748: 233-257.

Ross, H. A. 2014. The incidence of species-level paraphyly in animals: a re-assessment. Molecular Phylogenetics and Evolution, 76: 10-17.

Wiens, J. J. 2004. What is speciation and how should we study it? The American Naturalist, 163: 914-923.

Wiley, E. O. 1978. The evolutionary species concept reconsidered. Systematic Biology, 27: 17-26.

Submitted May 14, 2015

Accepted August 27, 2015 by Cláudio Oliveira Published December 15, 2015 